\title{
Effects of in-situ moisture conservation techniques on maize (Zea mays) yield and yield components in moisture deficit area of Dugda Woreda, Ethiopia
}

\begin{abstract}
Dulo Husen* and Zelalem Shalemew
Oromia Agricultural Research Institute, Adami Tulu Agricultural Research Center, P. O. Box 35, Batu, Ethiopia.

Received 3 July, 2019; Accepted 3 September, 2019

The study was conducted during 2018 cropping season at Dugda Woreda to investigate the effect of in situ moisture conservation techniques on grain yield and yield components of maize. Treatments comprised of tied ridge, furrow closed at both end and farmer's practices (as the control). The experiment was laid out in a Randomized Complete Block Design (RCBD) with three replication. The grain yield and thousand seed weight showed highly significantly difference $(p<0.001)$ on tied ridge and furrow closed at both end as compared to farmer practices. But the number of stand counts and cobs at harvest per hectare were not significantly $(p>0.05)$ varied on tied ridge, furrow closed at both end and farmer practice, respectively. Tied ridge practices had increases maize grain yield and thousand seed weight (g) by up to $45.52 \%$ ( 2.7913 ton ha-1) and $41.43 \%$ above farmer practice (control), respectively. Also furrow closed at both end increased the grain yield and thousand seed weight (g) by up to $30.68 \%$ (1.882 ton ha-1) and $27.63 \%$ as compared to farmers' practice, respectively. These results claim the potential use of tied ridge and furrow closed at both end improved grain yield and thousand seed weight in the study areas by enhancing moisture in the soil. Therefore, in situ moisture conservation (tied ridge and furrow closed at both end) structure is a promising moisture conservation structures to mitigate dry spell period and improve maize production in the study area and similarly agro ecology.
\end{abstract}

Key words: Tied ridge, furrow closed at both end, yield, moisture deficit.

\section{INTRODUCTION}

Agriculture in Ethiopia is dominated by rain fed farming with low productivity. The average annual grain production of 7 million tons is too low to support national food demands (Eyasu, 2005). Since rainfall is seasonal and erratic in dry lands of Ethiopia, there is moisture stress limiting the productivity of rain fed agriculture in the moisture stress areas (Haregeweyn et al., 2005). Food deficit in the whole of the country, dry land areas in particular is increasing mainly due to drought and moisture deficity (Kidane and Abuhay, 2000). Maize was ranked as the third place cereal consumed in the world after wheat and rice (Olaniyan, 2015), and the first yielded and productive cereal (FAOSTAT, 2015). It is an important food crop in sub-saharan Africa, 300 million

\footnotetext{
*Corresponding author. E-mail: dulohusen196@gmail.com.
} 
people in sub-sahara Africa consider maize as a primary source of food and livelihood (Macauley, 2015). It occupied $17 \%$ of cultivated land (FAOSTAT, 2015) and $21 \%$ in East Africa (Ndlovu, 2013). While most of sub Saharan Africa; maize production is based on rainfed systems (Gebrehiwot and Gebrewahid, 2016), there is a need to find out the alternative soil moisture conservation strategies to mitigate moisture deficit effect.

Moisture stress is a prolonged period of short precipitation resulting in water deficiencies and lack of soil moisture to support crop production (Solh and van Ginkel, 2014). It is a great hazard in the world which frustrate the productivity of agricultural crops (Aslam et al., 2015). Every year there is a loss of $25 \%$ crop yield globally caused by severe drought (Bankole et al., 2017) and 36 million people in sub sahara Africa are experiencing severe food shortage because of the drought and shortage of moisture in soil profile (Nazareth, 2016; Water Aid, 2017).

Low agricultural productivity in semi-arid region is not only due to land degradation, but also due to moisture deficit (Gebreegziabher et al., 2009). A study by Mekuria and Waddington (2004) noted the moisture stress being the major limitation to crops yield in cereal based cropping systems in Eastern and Southern Africa. Moisture retention structures plays a vital role for successful and sustainable crop production. Therefore, planting crops using in situ moisture conservation reduces problems of soil moisture stress by reducing runoff through increased infiltration and storage of water in the soil profile, the onset and occurrence of severe water stress is delayed thereby buffering the crop against damage caused by water deficits during dry periods (Nyamadzawo et al., 2013). In these regards using tied ridge and furrow closed at both end are some of the methods that contribute to mitigate soil moisture deficit and enhance maize productivity in semi arid and arid areas.

In East Shewa of Ethiopia, high moisture deficit is the primary problem which highly constrain the productivity of small holders' farmers of the Woreda (priority problems raised by farmers). In moisture scarce environments like Central Rift valley in general, particularly Dugda Woreda crop would face shortage of moisture available in the soil throughout the growing season. The major problem in this study area is unavailability of in situ moisture conservation techniques (Agricultural Production Constrain Analysis in East and North Shewa Zone, Oromia, Ethiopia, unpublished, 2017). Also the distribution of rainfall is not sufficient to sustain crop growth and development in the study area.

Accordingly, crop frequently suffers from moisture stress at some stage during its growth period with the ultimate result of reduced yield from their farmland because of shortage or uneven distribution of rainfall and absence conserving surface runoff within the catchment. There is currently no sufficient research works on evaluating the effectiveness of in situ moisture conservation techniques on improving maize yield in Dugda Woreda. Hence, the utilization of in situ moisture conservation structure is critically important to increase crop yield and improve food security.

\section{General objectives}

The general objective is to investigate the effects of in situ moisture conserving techniques on maize yield and relevant treatments in improving production in the study area.

\section{Specific objectives}

The specific objectives are to evaluate the impacts of in situ moisture conserving techniques on maize yield and to recommend relevant treatments with a view to improve the yield of maize.

\section{MATERIALS AND METHODS}

\section{Description of study area}

The field experiment was conducted at Dugda Woreda which is found in East Shewa zone of Oromia regional state. It is located at a distance of 140 and $95 \mathrm{~km}$ from Addis Ababa and Adama, respectively. Geographically, it is situated in the central rift valley between 8

respectively. Its elevation is 1600 meters above sea level (masl). The total annual rainfall and minimum and maximum temperature of the study area for 2018 cropping season is $795 \mathrm{~mm}, 13.6$ and $29.2^{\circ} \mathrm{C}$ respectively. The dominant soil type of the study area is sandy loam soil (Figure 1).

\section{Experimental design and treatments}

The experiment was conducted for a period of one year (2018) at the three selected kebeles of Duda Woreda under rain fed condition on farmers' farmland, to investigate the effects of in situ moisture conservation on maize yield and yield components. The three kebeles of study area were selected purposively on the basis of its maize production and moisture deficit. The two farmers for each kebele were selected purposively based on their willingness and recommendation by woreda agricultural expert and Development agent (DA) for conducting experiment. The experiment was laid out in a Randomized Complete Block Design (RCBD) with three replications. Three levels of treatments (Farmer practice(control), Furrow Closed at both End and Tied ridge) were used and conducted on similar slope.

Each treatment was applied on a plot size of $10 \mathrm{~m} \times 10 \mathrm{~m}$ (100 $\mathrm{m}^{2}$ ) separated by a distance of $1 \mathrm{~m}$ between blocks and $1 \mathrm{~m}$ within plots. The height of ridge and tie was $30 \mathrm{~cm}$ and $20 \mathrm{~cm}$, respectively. Maize was planted at spacing of $25 \mathrm{~cm}$ between plant and $75 \mathrm{~cm}$ between plots. The $\mathrm{BH}-540$ maize variety was used as testing crop.

\section{Preparation of in situ moisture conservation structures}

All experimental plots were ploughed three times by oxen plough 


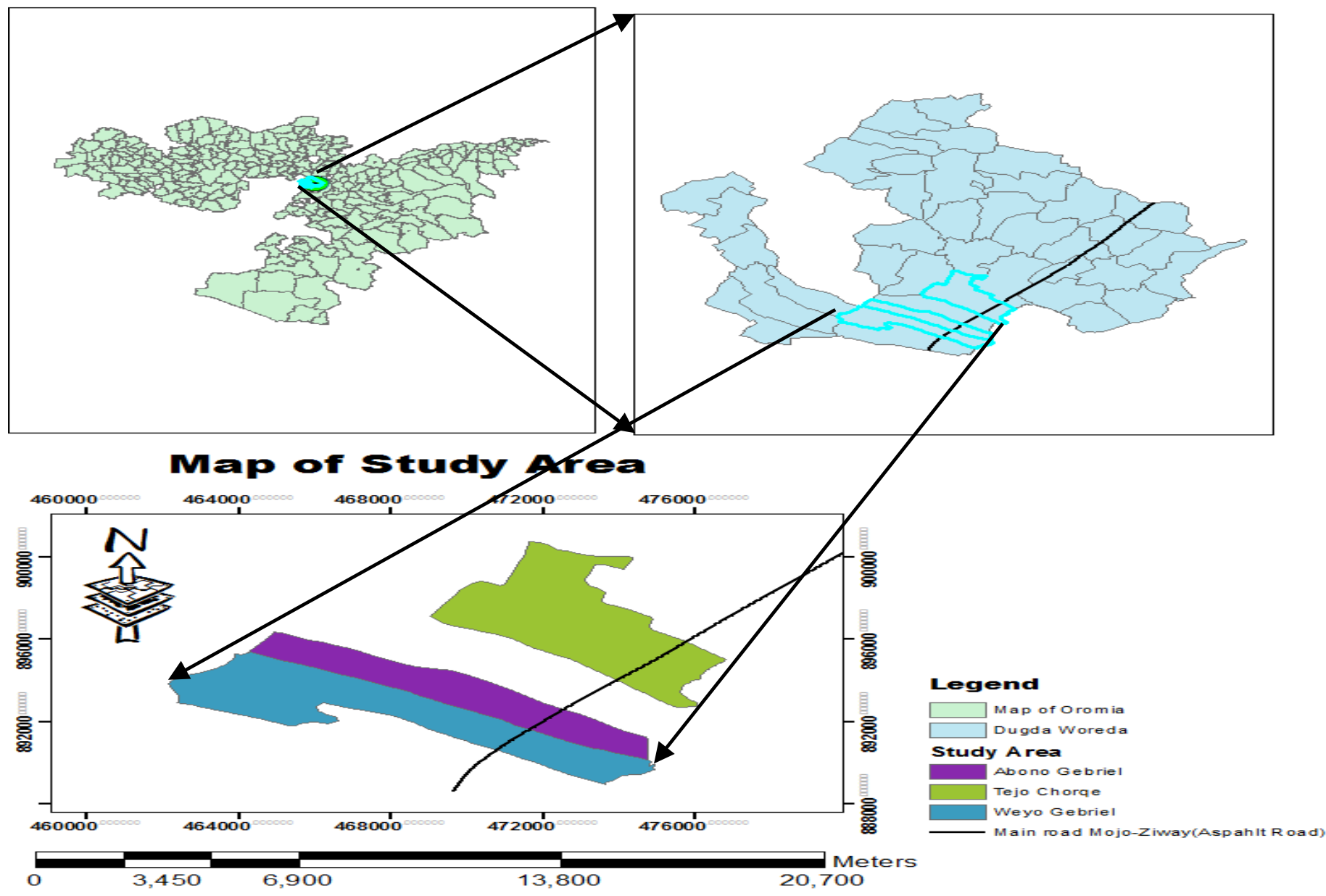

Figure 1. Map of study area.

using the local maresha before imposing any of the treatments. In tied ridging, ridge furrows are blocked with earth ties at $3.3 \mathrm{~m}$ distance apart from one another to form a series of micro catchment basins in the field. The furrow was closed at both end at spacing of $10 \mathrm{~m}$. The tied ridge was prepared by hand hoe. The tied ridge was prepared after planting maize crop. The structure preparation and status of maize crop was illustrated in Figure 2.

\section{Farmer Research Extension Group (FREG) establishment and min field day}

The selected farmers were organized under Farmers Research Extension Group (FREG) to increase farmers awareness on in situ moisture conservation structures in view of improve maize yield in moisture deficit area. Three Farmers Research Extension Group (FREG) members were established one at each kebele's. Each FREG members were held; 15 farmers and a total of 45 farmers participated in the project; from this, $40 \%$ of them were women and $60 \%$ of them were men; household farmers participated on min field day and became aware of the importance's of in situ moisture conservation structure. Two (2) subject matter specialist (SMS) from Woreda Agriculture and Natural Resource Bureau and six (6) Development Agents (DAs) participated in min field day (Figure 3). The directly benefited farmers played the role of information sharing to other farmers, recording and providing information and taking an active participation in all the way from site selection, construction of in situ moisture conservation to harvesting.

The researchers explained the whole process and discussions were made in response to the queries raised from the farmers and experts. The raised issues during min field day were uneven distributions of rainfall and crop in the study area deteriotate due to moisture stress problems and also the importance of using in situ moisture conservation structures in improving crop yield in the study area. In general, the farmers were convinced by the technology and some of them made a decision to construct in situ moisture conservation structures on their own land in the future. Moreover, field day were organized for further demonstration purpose.

\section{Data collection}

Measured parameters includes plant height, yield per hectare, plant stand counts at harvest per hectare, number of cobs per hectare, thousand weight of seeds and yield advantage. The plant height was recorded by taking the random five plants from the central three rows of the net plot area $(2.25 \mathrm{~m} \times 10 \mathrm{~m})$ of each plot. Yield was recorded from the central three rows of the net area of $2.25 \mathrm{~m}$ $\times 10 \mathrm{~m}$ by excluding the border rows. Yield per plot was recorded from air-dry weight of seeds of the net plot area $(2.25 \mathrm{~m} \times 10 \mathrm{~m})$ 


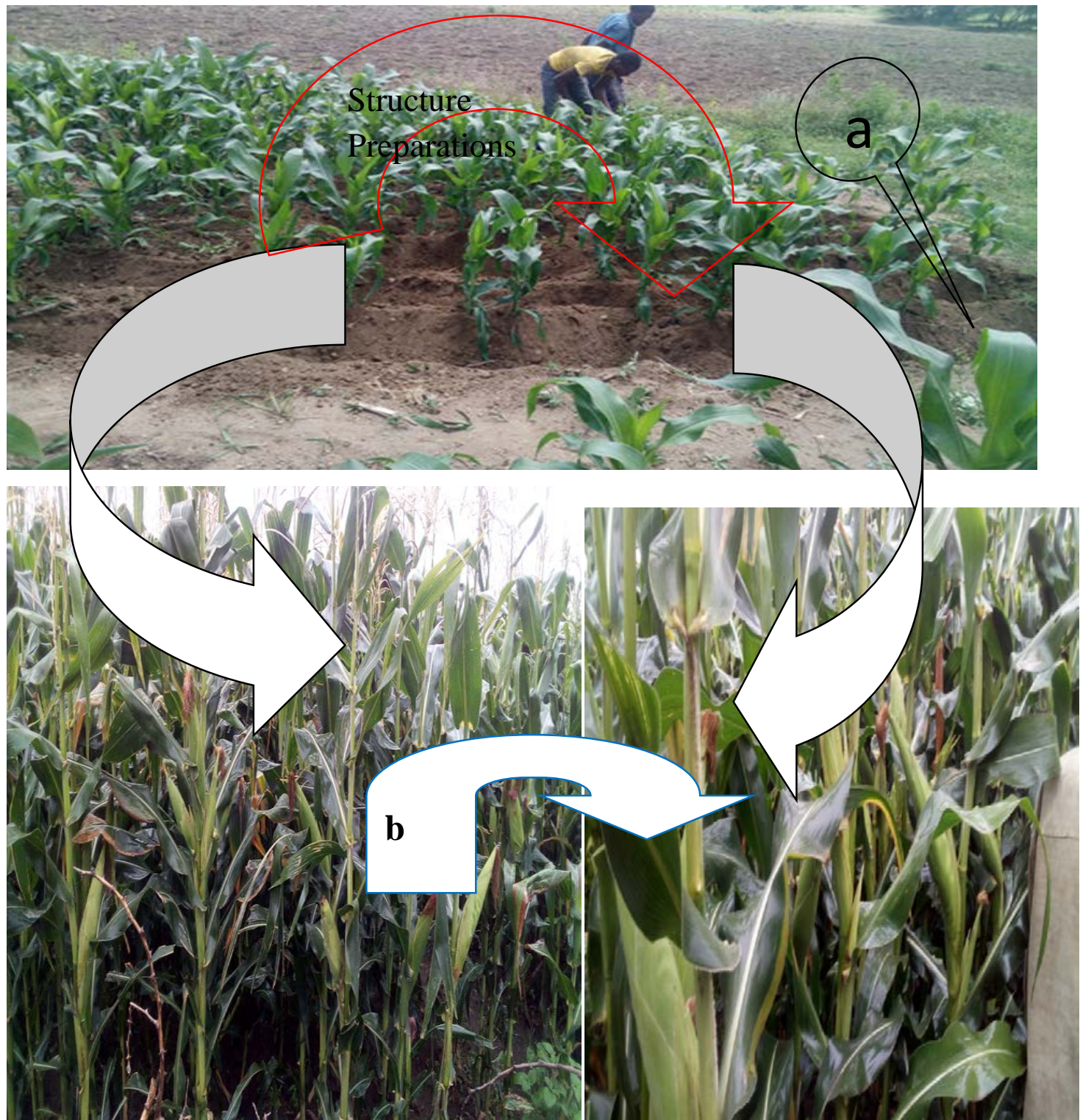

Figure 2. Preparation of in situ moisture conservation structure (a) and status of maize crop (b).

and expressed as ton $\mathrm{ha}^{-1}$. The plant stand counts and number of cobs (heads) per hectare were determined by counting the number of plants in the net area for the three rows $(2.25 \mathrm{~m} \times 10 \mathrm{~m})$. Thousand weight of seeds was determined by counting thousands seed dry seeds and their weight are recorded in grams.

The yield advantage (\%) of using moisture conservation structure is calculated using the following equation and analyzed using descriptive statistics.

Yield advantages $(\%)=\frac{\text { Yield with structure }- \text { Yield without structure }}{\text { Yield without structure }} * 100(1)$

\section{Data analysis}

The $R$ analytical software version 3.5.2 was used to analyze the data. Analysis of Variance (ANOVA) was used to determine effect of the in situ moisture conservation structure method on yield and yield components parameters of the maize. Mean separation least significant difference (LSD) was used to compare and separate treatment means at $5 \%$ probability level.

\section{RESULTS AND DISCUSSION}

\section{Grain yield}

The grain yield was highly significant $(P<0.001)$ to in situ moisture conservation (tied ridge and furrow closed at both end) techniques. The mean yield indicated in Table 1 revealed that grain yield was significantly increased on tied ridge as compared to farmer practice. And the mean yield of maize significantly increased on furrow closed 

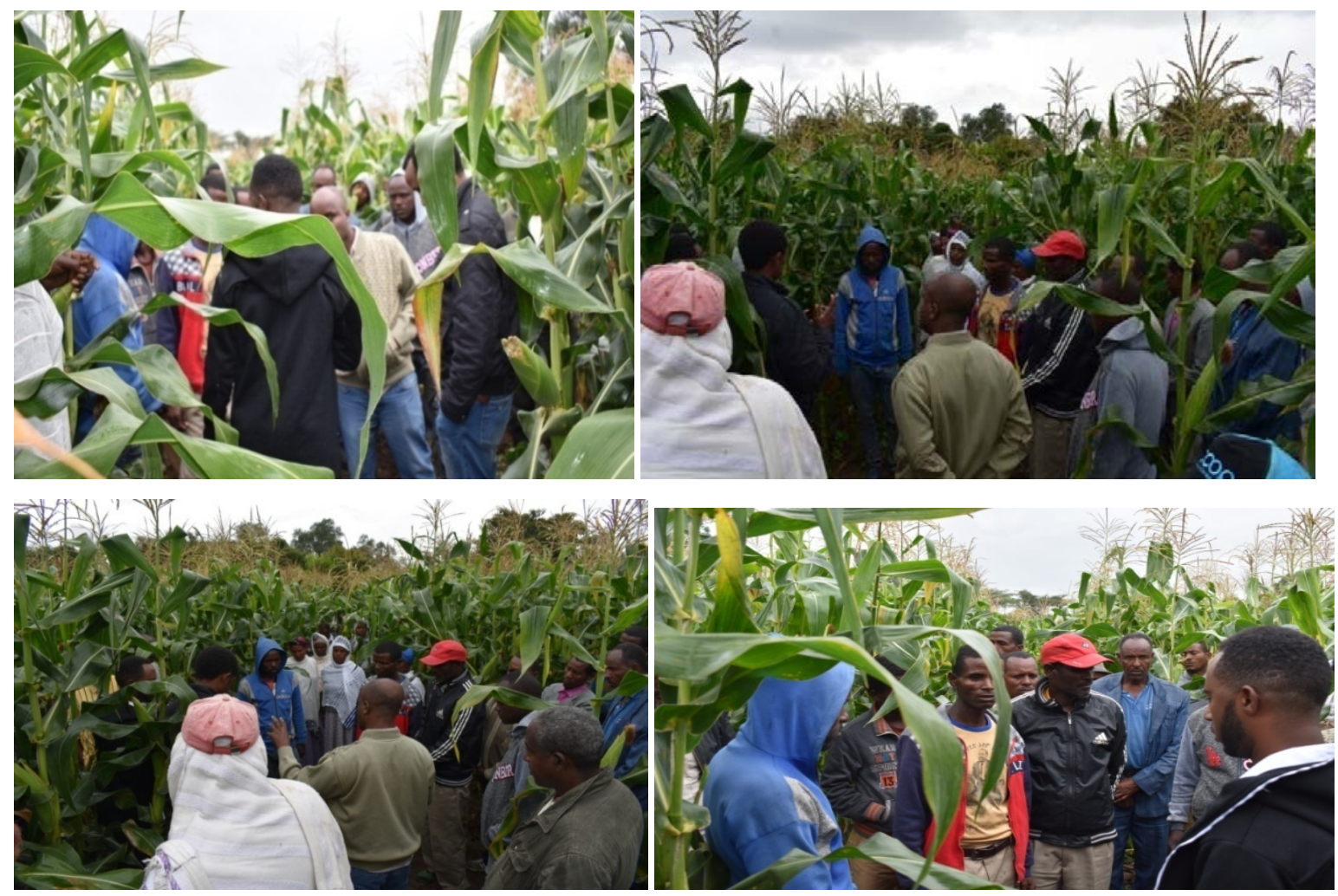

Figure 3. Min-Field day at Dugda woreda,2018 crop season.

Table 1. Mean yield and yield components of maize as affected by tied ridge and furrow closed at both end.

\begin{tabular}{|c|c|c|c|c|c|c|}
\hline Treatment & $\begin{array}{l}\text { Plant height } \\
\text { (cm) }\end{array}$ & $\begin{array}{c}\text { Stand count at } \\
\text { harvest/ha }\end{array}$ & $\begin{array}{c}\text { Number of } \\
\text { cobs/ha }\end{array}$ & Yield (tonha ${ }^{-1}$ ) & $\begin{array}{l}1000 \text { seed } \\
\text { weight(g) }\end{array}$ & $\begin{array}{c}\text { Yield } \\
\text { advantage (\%) }\end{array}$ \\
\hline TR & $214.51^{a}$ & $74,675^{a}$ & $74,675^{a}$ & $8.922^{a}$ & $410.83^{a}$ & 45.5 \\
\hline FCE & $213.79^{a}$ & $71,500^{\mathrm{a}}$ & $71,500^{\mathrm{a}}$ & $8.013^{a}$ & $370.73^{a}$ & 30.68 \\
\hline FP & $211.05^{a}$ & $62,750^{\mathrm{a}}$ & $62,500^{\mathrm{a}}$ & $6.132^{b}$ & $290.47^{b}$ & \\
\hline Mean & 213.12 & $69,641.67$ & $69,558.33$ & 7.689 & 357.34 & \\
\hline CV(\%) & 8.4 & 20 & 19.99 & 17.5 & 13.61 & \\
\hline
\end{tabular}

Treatment values within a column followed by the same letter are not significantly different at $0.1 \%$. TR: Tied Ridge; FCE: Furrow closed at both End; FP: Farmer Practies; CV: Coefficient of variation; LSD: Least of significance Difference; * and ${ }^{* \star}$ level of significance at $\mathrm{P}<0.05$ and $\mathrm{P}<0.001$ respectively and $\mathrm{ns}=$ not significant difference.

at both end as compare to farmer practice. The higher grain yield of maize obtained from the structure of tied ridge is attributed to the greater infiltration and storage of water in soil; which gives plants ample time to take up the stored water as compared to the farmer practice. This finding agrees with many researchers Heluf (2003), Gebreyesus (2004) and Taye and Yifru (2010) had also reported the importance of tied ridge is increasing crop yield by increasing the time for the water to penetrate into the soil.

Similarly, Solomon (2015) reported that the grain yield of early maturing maize varieties was significantly affected by in situ moisture conservation practices. The recorded maximum yield from the tied ridge might be attributed to the efficiency of tied ridge to conserve and retain moisture when compared to the other moisture conservation practices. This result is also in conformity with the findings of Mudalagiriyappa et al. (2012) who reported that the increased yield of maize could be attributed to the reduced surface runoff and reduced risk of erosion and soil nutrients and to increased water holding capacity of the soil in insitu moisture conservation 
structure. But, there was no significant differences $(p>$ 0.05 ) in yield between the tied ridge and furrow closed both end techniques (Table 1).

\section{Plant height, stand count and number of cobs per hectare}

There were no statistically significant differences $(p>$ $0.05)$ between treatments concerning plant height $(\mathrm{cm})$ and stand count and number of cobs per hectare (Table 1).

\section{Thousand seed weight}

The thousand seed weight were highly significantly $(p<$ 0.001 ) difference on tied ridge and furrow closed at both end as compared to farmer practices (Table 1 ). This implied that in situ moisture conservation structures improve thousands seed weight by retaining surface runoff and increase infiltration within the catchment. In fact, the seeds which were supplied with adequate moisture did mature well to have heavier seed weight than farmer practice. This could be attributed to the fact that the relatively higher soil moisture accumulated in the furrows and ridges of the tied ridging system permitted late maturity of the crop and as a result giving enough time for the maize plant to develop their seeds properly with adequate and continued moisture supply. A result reported by Gebreyesus (2004) on the effects of in situ soil moisture conservation on thousand seed weight was similar with the findings of this study. But, there was no significant difference $(p>0.05)$ in thousands seed weight between the tied ridge and furrow closed both end techniques (Table 1).

\section{Plant height}

The highest and least plant heights of 214.51 and 211.05 $\mathrm{cm}$ were obtained from tied ridge and farmers' practice, respectively (Table 1 ). The furrow closed at both end had better plant height than farmer practices. But statistically, there was no statistically significant difference between the treatments regarding plant height. The mean of plant height on tied ridge and furrow closed at both end were better than farmer practice; this could probably be as a result of the merits of these structures (tied ridge and furrow closed at both end). Within this study; tied ridge and furrow closed at both end relatively gave high plant height as compare to farmer practices due to high efficiency in moisture retention capacity.

\section{Yield advantages over farmer fractice}

The grain yield and thousand seed weight advantage of $45.5 \%\left(2.79\right.$ ton $\left.^{-1}\right)$ and $41.43 \%$ were obtained from tied ridge over the farmers' practice, respectively. Also the yield and thousand seed weight advantages of $30.68 \%\left(1.88\right.$ ton $\left.\mathrm{ha}^{-1}\right)$ and $27.63 \%$ were obtained from furrow closed at both end respectively (Table 1). This implies that the two structures have a capacity to retain more surface runoff within catchment and infilitrate in soil than farmer practice. This could be attributed to increase grain yield and thousand seed weight in study area; and this result agrees with the previous findings of Heluf and Yohannes (2002) who reported that, tied ridge, has resulted in yield increments of 15 to $50 \%$ on maize and yield increment of 15 to $38 \%$ was recorded for sorghum on different soil types of eastern Ethiopia. Similarly, Jensen et al. (2003) stated that maize grain yield with tied ridging in year with dry to near normal rainfall was improved by $42 \%$ even without any nutrient inputs while the seasonal average runoff was between 5 to $9 \%$ in the plots with water conservation and 16 to $30 \%$ in the plots without water conservation. Also Araya and Stroosnijder (2010) and Walker et al. (2005) have stated that single interventions through water conservation could improve crop yield by up to $50 \%$ in arid and semi-arid regions of sub-Saharan Africa. Thus, practicing in situ moisture conservation structures is imperative and positively increase significance difference in grain yield and thousand seed weight in moisture deficit area.

\section{Summary}

In situ moisture conservation techniques at farm level are essential options for the moisture deficit area of Dugda woreda for improving yield through better soil water storage. Tied ridge and furrow closed at both ends were the paramount practice because of its high mean grain yield and thousand weight seed response. From all treatments, tied ridge gave higher mean yield and thousand seed weight advantages than farmers practices in study area. Similarily, furrow closed at both end gave high mean yield and thousand seed weight advantages than farmers practices in study area.

The grain yield and thousand seed weight were highly significantly $(p<0.001)$ difference on tied ridge and furrow closed at both ends as compared to farmer practices. This implies that the grain yield and thousand seed weight increased significantly according to the availability of water in the treatments. Thus, practicing in situ moisture conservation structures is imperative, and positively increase significance difference in grain yield and thousand seed weight in the study area. Therefore, it could be concluded that ensured soil moisture availability through the use of in situ moisture conservation structures can increase maize production in the study area and similar agro-ecology.

\section{CONCLUSIONS AND RECOMMENDATIONS}

Based on the findings obtained from one cropping 
season, the farmers were advised to use tied ridge first recommendation and furrow closed at both end as the second options to increase maize productivity in the study area. Therefore, in situ moisture conservation (tied ridge and furrow closed at both end) structures should scale up on wider areas of similar agro ecology to assure food security of the country, particularly in Dugda woreda. There is need to disseminate the results of the present study to the end users (Farmers, subject matter specialist, DAs and others stakeholder). The future study should focused on integration of in situ moisture conservation with mulching on yield and yield components in the study area and similar agro ecology.

\section{CONFLICT OF INTERESTS}

The authors have not declared any conflict of interests.

\section{ACKNOWLEDGEMENTS}

The authors would like to thanks Agricultural Growth Program II(AGP-II) for financing the project. Also he would like to express his appreciation to all staff of Soil and Water Engineering Research Team of Adami Tulu Agricultural Research Center for their active participation in conducting this experiment.

\section{REFERENCES}

Aslam M, Maqbool MA, Cengiz R (2015). Drought stress in maize (Zea mays L.): effects, resistance mechanisms, global achievements and biological strategies for improvement. Springer.

Araya A, Stroosnijder L (2010). Effects of tied ridges and mulch on barley (Hordeum vulgare) rainwater use efficiency and production in Northern Ethiopia. Agricultural Water Management 97:841847.

Agricultural Production Constrain Analysis in East and North Shewa Zone Oromia, Ethiopia, Unpublished, 2017.

Bankole F, Menkir A, Olaoye G, Crossa J, Hearne S, Unachukwu N, Gedil M (2017). Genetic gains in yield and yield related traits under drought stress and favorable environments in a Maize population improved using marker assisted recurrent selection. Frontiers in Plant Science 8(808).

Eyasu Y (2005). Development and Management of Irrigated lands in Tigray, Ethiopia. PhD Thesis, Department of Water Engineering, UNESCO-IHE Institute for water Education Delft, The Netherlands.

FAOSTAT (2015). Food and Agriculture Organization of the United Nations Statistical Database. Rome Italy: Pocketbook.

Heluf G, Yohannes U (2002). Soil and water conservation (tied ridgesand planting methods) on cultivated lands: The case of eastern Ethiopian; Soil and Water Management Research Program, Alemaya University (AU) $154 \mathrm{p}$.

Heluf G (2003). Grain Yield Response of Sorghum (Sorghum bicolor) to Tied Ridges and Planting Methods on Entisols and Vertisols of Alemaya Area, Eastern Ethiopian Highlands Journal of Agriculture and Rural Development in the Tropics and Subtropics 104(2):113-128.
Gebreegziabher T, Nyssen J, Govaerts B, Fekadu G, Mintesinot B, Mitiku H, Deckers J (2009). Contour furrows for in situ soil and water conservation, Tigray, Northern Ethiopia. Soil and Tillage Research, 103:257-264.

Gebrehiwot KA, Gebrewahid MG (2016). The need for agricultural watermanagement in sub-Saharan Africa Journal Water Resources and Protection 8(1):835-843.

Gebreyesus BT (2004). Tied Ridging as In-situ Rainwater Harvesting Methods for Improving Sorghum Yield at Abergelle Area, Tigray Regional State. An M.sc. Thesis submitted to Haremaya University.

Haregeweyn N, Poesen J, Verstraeten G, De Vente J, Govers G, Deckers S, Moeyersons J (2005). Specific sediment yield in Tigray-Northern Ethiopia: Assessment and semi-quantitative modelling. Geomorphology 69, 315-331.

Jensen JR, Berhard RH, Hasen S, MulchingDonagh J, Moberg JP, Nielsen NE, Nordbo E (2003). Productivity in maize based cropping systems under various soil water management strategies in a semi-arid, alfisol environment in East Africa. Agricultural Water Management 59:217-237.

Kidane G, Abuhay T (2000). A Manual for Semi-arid Areas of Ethiopia: Resource Base, Constraints and Improved Technologies for Sustainable Agricultural Production, mimeo. EARO, Addis Ababa, Ethiopia

Macauley H (2015). Feeding Africa, Cereal Crops: Rice, Maize, Millet, Sorghum, Wheat pp. 1-36.

Mekuria M, Waddington S (2004). Institutional and Policy Support Is Essential to Promote the Adoption of Soil Fertility Technologies on Maize-Based Smallholder Farms in Southern Africa. Proceedings of the 4th International Crop Science Congress, Brisbane.

Nazareth V (2016). Evaluating conservation agriculture and its adoption potential in developing countries (Master Dissertation). University of Florida

Ndlovu E (2013). Impact of tree species on maize productivity by smallholder farmers in eastern Kenya (Master Dissertation). Kenya: Jomo Kenyatta University.

Nyamadzawo G, Wuta M, Nyamangara J, Gumbo D (2013). Opportunities for optimizing in field water harvesting to cope with changing climate in semiarid smallholder farming areas of Zimbabwe. Springer plus 2:1-9

Olaniyan AB (2015). Maize: Panacea for hunger in Nigeria.African Journal of Plant Science 9(3):155174.http://dx.doi.org/10.5897/Ajps2014.1203.

Solh M, van Ginkel M (2014). Drought preparedness and drought mitigation in the developing world's drylands. Weather and Climate Extremes 3(1):62-66.

Solomon T (2015). On-farm verification of the effects of selected soil moisture conservation techniques on yield and yield components of early maturing maize varieties at Bako, western Ethiopia. International Journal of Advanced Earth Science and Engineering 4(1):254-264.

Taye B, Yifru A (2010). Response of maize (Zea mays L.) to tied ridges and planting methods at Goro, Southeastern Ethiopia. American-Eurasian Journals if Agronomy 3(1):21-24.

Walker S, Tsubo M, Hensley M (2005). Quantifying risk for water harvesting under semiarid conditions. Part II. Crop yield simulation. Agricultural water management 76:94-107.

Water Aid (2017). Wild water: The state of the world's water 1(24):1-24. 